\title{
THE ROLE OF SCHOOL SEXUAL EDUCATION IN HEALTH PROMOTION
}

\section{ROLA SZKOLNEJ EDUKACJI SEKSUALNEJ W PROMOCJI ZDROWIA}

\author{
Joanna Skonieczna $^{1(\mathrm{~A}, \mathrm{~B}, \mathrm{C}, \mathrm{D}, \mathrm{E}, \mathrm{F})}$, Dominik Olejniczak ${ }^{1(\mathrm{D}, \mathrm{E})}$
}

\author{
${ }^{1}$ Department of Public Health, Medical University of Warsaw
}

Authors' contribution Wkład autorów:

A. Study design/planning zaplanowanie badań B. Data collection/entry zebranie danych

C. Data analysis/statistics dane - analiza i statystyki

D. Data interpretation interpretacja danych E. Preparation of manuscript przygotowanie artykułu F. Literature analysis/search wyszukiwanie i analiza literatury G. Funds collection zebranie funduszy
Tables: 1

Figures: 0

References: 40

Submitted: 02.06.2015

Accepted: 14.02 .2016

\begin{abstract}
Summary
Sexuality is an integral part of personality of each human being. No earnestly conducted sex education is a common cause of engaging in risky sexual behaviours.

The aim of the study is to evaluate the role of sex education in health promotion and to present the results of the studies of the effects of school sex education on sexual behaviour of young people.

The period of adolescence is characterized by a more frequentrisk-taking behaviour. Among adolescents it is observed that the average age of sexual initiation has decreased, the frequency of making sexual contact and a number of sexual partners has increased, as well as the insufficient dissemination of the use of condoms and other methods of contraception every time sexual intercourse takes place.

The task of health promotion is to influence determinants of health, among others, through sex education. Research confirms the positive impact of complex sex education, carried out in accordance with the recommendations of international organizations, on a lower frequency of engaging in risky sexual behaviour. It seems appropriate to take action to disseminate appropriate for the level of psychosexual development sex education in schools.
\end{abstract}

Keywords: sex education, health promotion, school

\section{Streszczenie}

Seksualność jest nieodłącznym elementem osobowości każdego człowieka. Brak rzetelnie prowadzonej edukacji seksualnej w tym zakresie jest częstą przyczyną podejmowania ryzykownych zachowań seksualnych.

Celem pracy jest ocena roli edukacji seksualnej w promocji zdrowia oraz zaprezentowanie wyników badań oceniających wpływ szkolnej edukacji seksualnej na zachowania seksualne młodzieży.

Okres adolescencji charakteryzuje się częstszym podejmowaniem ryzykownych zachowań. Wśród adolescentów obserwowany jest spadek średniego wieku inicjacji seksualnej, zwiększenie częstości podejmowania kontaktów seksualnych oraz liczby partnerów seksualnych, a także niedostatecznie rozpowszechnienie korzystania z prezerwatyw i innych metod antykoncepcji przy każdym stosunku seksualnym.

Zadaniem promocji zdrowia jest wpływanie na uwarunkowania zdrowia m.in. poprzez edukację seksualną. Badania potwierdzają pozytywny wpływ złożonej edukacji seksualnej, prowadzonej zgodnie z rekomendacjami organizacji międzynarodowych, na mniejszą częstotliwość podejmowania ryzykownych zachowań seksualnych. Właściwe wydaje się być podjęcie działań mających na celu rozpowszechnianie właściwej dla poziomu rozwoju psychoseksualnego edukacji seksualnej w szkołach.

Słowa kluczowe: edukacja seksualna, promocja zdrowia, szkoła

Skonieczna J, Olejniczak D. The role of school sexual education in health promotion. Health Problems of Civilization 2016; 10(1): 46-54. DOI: $10.5114 / \mathrm{hpc} .2016 .58208$

\section{Aim of the work}

The aim of the study is to evaluate the role of sex education in health promotion and to present the results of studies of selected authors evaluating the relationship of school sex education on sexual behaviour of young people.

\section{Brief description of the status of knowledge}

\section{Grounds for conducting sex education}

Sexuality is an integral part of the personality of each human being. The World Health Organization (WHOcalled. World Health Organization) provides the following definition of sexual health: "Sexual health is the wellbeing physically, emotionally and socially in relation to sexuality; it is not merely the absence of disease or infirmity

Address for correspondence / Adres korespondencyjny: Joanna Skonieczna, Department of Public Health, Medical University of Warsaw, Banacha 1a, 02-097 Warszawa, e-mail: jskonieczna90@gmail.com, phone: +48225992108

Copyright: (C) 2016 Pope John Paul II State School of Higher Education in Biała Podlaska. This is an Open Access journal, all articles are distributed under the terms of the Creative Commons Attribution-NonCommercial-ShareAlike 4.0 International (CC BY-NC-SA 4.0) License (http://creativecommons.org/licenses/by-nc-sa/4.0/), allowing third parties to copy and redistribute the material in any medium or format and to remix, transform, and build upon the material, provided the original work is properly cited and states its license. 
dysfunction (...). To achieve and maintain sexual health, sexual rights should be respected, protected and fulfilled" [1]. Thus, the definition of sexual health also refers to sexual rights. Sexual rights were formulated by the World Health Assembly in the Universal Declaration of Sexual Rights, whose most recent version was published in 2014 [2].

Declaration of Sexual Rights refers only to adults. Children's rights are contained in the Convention of the United Nations (UN) on the Rights of the Child, which was ratified by Poland in 1991 [1]. Committee on the Rights of the Child obliges State parties to ensure that minors have access to knowledge in the field of sexuality and reproduction covering such topics as: family planning methods and contraceptives, the risks associated with early pregnancy and prevention of sexually transmitted diseases, regardless of the consent of the parents / legal guardians or marital status of minors. This means that the school should be ensured at all levels of education, classes on sex education, which will be adjusted to the age of the students [3].

In Poland, the obligation of sex education in schools is set out in Article. 4 of the Act of 7 January 1993 on family planning, protection of the human fetus and conditions of permissible abortion notes "Knowledge on human sexual life, on principles of conscious and responsible are introduced to the school curriculum as well as on parenthood, family values, life in the prenatal stage and methods and means of conscious procreation (...) “ [4] .

The manner in which the subject of Education for family life is executed (WDZ) is defined in the Regulation of the Minister of National Education of 12 August 1999 on the way of school education and the scope of contents concerning the knowledge on human sexual life, on principles of conscious and responsible parenthood, family values, life in the prenatal stage and methods and means of conscious procreation contained in the core curriculum of general education [5].

Classes on sex education are implemented on the basis of binging since the school year $2009 / / 2010$ new core curriculum regulated by the Regulation of the Minister of National Education of 23 December 2008. on core curricula for pre-school education and general education in particular types of schools (Dz. U. of 2009. No. 4, pos. 17) replaced the Regulation of the Minister of National Education of 27 August 2012. on core curricula for preschool education and general education in the different types of schools (OJ 2012 No. 0 pos. 977) .

These documents show the importance of sexual health care for every human being and free access to information on sexuality. The state has the obligation to provide adequate sexual education and not discriminate against anyone in this regard.

According to the standards, sexual education is defined as "the science of cognitive, emotional, social, interactive and physical aspects of sexuality. Sex education begins in early childhood and is carried further into adolescence and adulthood. In the case of children and young people in order to support and protect the sexual development" [1]. International Guidelines on Sexual Education were developed by the Organization of the United Nations. Educational, Scientific and Cultural Organization defines sexual education as "adjusted to the age and cultural way of teaching about sex and relationships, providing accurate, realistic, non-judgemental information. Sex education provides the opportunity to "research" one's own values and attitudes that enables us to acquire decision-making skills, communication and risk reduction with respect to many aspects of sexuality" [6].

Sex education is conducted in a just way and transmitting the current knowledge in scientific manner it enables children and adolescents to broaden the knowledge, skills acquisition, as well as acquiring positive values. In the future, it greatly increases the chance of correct understanding of one's own sexuality, creating fulfilled and secure relationships and a sense of responsibility for one's own sexual health.

In accordance with the Standards of sexual education in Europe the following types of sex education are distinguished:

Type 1 - "abstinence only", which is based on promoting abstinence. The following behaviours are condemned: having sex before and outside of marriage, contraceptive methods (except the so-called Natural methods), abortion, masturbation, oral and anal sex, orientations other than heterosexual. The administration of Republican states in the USA strongly promoted and supported this type of program $[1,7,8]$.

Type 2. - general sex education, the aim of which is to provide the full knowledge of contraception and abortion, which are not condemned. Sexual abstinence is presented as an option. There is acceptance for the intercourse before and outside of marriage (except when it's illegal), various activities of sexual taken for the free and informed consent of all individuals participating in them, as well as masturbation and other sexual orientations $[1,7,8]$.

Type. 3. - "holistic sex education" in the English literature referred to as Sex and Relationship Education (SRE). It is characterized by the fact that the above aspects are presented depending on the sexual development of recipients. Sexual intercourse is an important value in human life, but inseparable from one other. It combines sexual awareness with shaping positive attitudes. The feeling of love, maturity and responsibility are developed conditions for recognition before and extramarital relations. The institution of marriage is important but forms of creating relationships are not limited. The following are accepted: masturbation and contraceptives as a method of preventing unwanted pregnancies and STD. Sexual orientation other than heterosexuality are treated as equivalent 
to a heterosexual one. Abortion is a negative phenomenon, but there are circumstances in which access to abortion seems to be expedient, for example, in the absence of a properly conducted sex education. Sex education type 3 is conducted, among others in Canada [1, 7, 8, 9].

\section{The role of sex education in promoting sexual health}

Sexual activity of young people is one of the areas of interest of public health. It is associated with phenomena such as sexual initiation, pregnancy, sexually transmitted disease (STD) and sexual violence [10]. A common cause of making risky sexual behaviour is the lack of sex education conducted fairly. In Poland, neither family nor school fulfil its role in the field of sex education in a satisfactory manner. There is a phenomenon of shifting this obligation by institutions to one another. Parents, even those declaring desire to educate their children, have problems with speaking with them about issues of sexuality. This may be due to a lack of sufficient knowledge and skills in this area. Teenagers are ashamed or afraid of talking about sex with their parents [11]. In addition, the influence of the Church and youth organizations (eg. Scouts) which were potentially developing young people's positive behaviour and values nowadays has weakened. The fact that young people themselves do not attach significance to sexual and reproductive health may be problematic. An increasingly important role in transferring knowledge and creating behaviours is played by mass media [10].

According to the WHO - defined directions, activities in the field of health promotion in sexual health should: create positive attitudes towards sexuality; take into account the complex conditions and factors that determine sexual behaviour, relationships and satisfaction; to prevent any form of segregation, isolation and discrimination based on sexual orientation, gender, disability and general health; prevent sexual violence; seek to establish legal norms that would guarantee free access to counselling and therapy, and to broaden this access; strive for broad access to modern methods of contraception; include the prevention of STDs; promote safer sex and take into account the cultural traditions of a society [12].

Sexual activity of adolescents and young adults may present a risk of gynaecological complications, sexually transmitted diseases, emotional disorders (eg. Fear of sexual contact), disorders in the creation / development interactions, sexual behaviour, as well as unplanned pregnancy and its consequences [12].

Honestly led sex education is aimed at preventing the negative consequences of sexual activity of teens and young adults, developing assertiveness and responsible decision-making [13]. The following is a role of sex education in the prevention of some negative consequences of sexual activity of young people.

\section{Age of sexual initiation, number of sexual partners and frequency of sexual activity taking}

Sexual initiation is defined as "the first sexual intercourse" [10]. According to the Polish legal norms premature sexual activity is determined at the age of 15 (Law of 6 June 1997. Criminal Code) [14]. The first sexual intercourse is one of the most important events in one's life, and marks the transition to the next phase of psychosexual development. Participating in sexual intercourse should include full biological, psychological and social maturity. The fulfilment of these conditions allows young people to develop a sense of responsibility for their sexual activity and its consequences, and to build respect for sexual partner [15].

Social and biological change that have taken place over the last century caused a lowering of the age of sexual initiation and changed the understanding of this concept $[10,16]$. In Western Europe there was a decrease in the average age of initiation by nearly 2 - 3 years since 1960. The same changes occurred in eastern Europe, but about 20 - 30 years later. In the years 1998 - 2002, among 15-year-olds in the area of 29 European countries, the percentage declaring sexual initiation was varied and ranged among girls from 3.6\% (in Macedonia) to 40.4\% (in England) among boys from $18 \%$ (Spain) to $47.2 \%$ (in Ukraine) [17, 18].

Most Canadians' first sexual intercourse takes place during the teenage years. Percentage of 18/19 year olds who have ever had sexual intercourse decreased from 70\% in 1996/1997 to 65\% in 2005 [19].

A study in 2000 indicated that among Poles the average age of initiation was then 19 years (for women - 19.4, men - 18.6) [16]. A study conducted in 2005 among respondents aged 15 - 49 years of age showed a decrease to 18.08 for men and 18.82 for women. According to another study $47.3 \%$ of girls and $49.9 \%$ of boys in the age of eighteen have already had sexual initiation, of which $13.9 \%$ of girls and $19.4 \%$ boys have experienced this before they have completed fifteen years of age. The average age of initiation was 16.8 years for girls and 16.5 years in boys [10]. Research by Institute of Educational Research among young adults showed that $51 \%$ of the respondents ( $48 \%$ women and $53 \%$ men) have already had sexual intercourse. In this group of people, sexual intercourse took place for the first time at the age of 15 or less - for almost $10 \%$ of respondents, aged $16-18 \%, 17$ years - 26\%, 18 years or more $-24 \%$ [20]. In summary, men experience sexual initiation earlier than women, it is also observed that the age of initiation has lowered for both sexes. 
Review by Kirby showed that sex education can be a factor protecting from or inducing early sexual initiation. This may be due to the way in which it is conducted [21].

The analysis of studies on sexual education programs in the United States, carried out by SIECUS (The Sexuality Information and Education Council of the United States), has indicated that complex sexual education is one of the most effective methods of delaying sexual initiation among the youth. This type of sexual education does not encourage teenagers to have sexual intercourse or to increase the frequency of sexual relations and does not influence the growth of the number of sexual partners. The program increases the average age of sexual initiation and the popularity of condoms and other contraception methods as well as reduces the sexual intercourse frequency and the number of partners [22].

Meta-analysis of 83 studies conducted in many countries has shown that a significant proportion of sexual education programs delayed the moment of sexual initiation, while only one of them accelerated it. Among 52 studies, that have measured the impact on the start of sexual intercourse, 22 (42\%) programs have delayed sexual initiation by at least 6 months, in 29 (55\%) there was no significant association and only in one case (in the US) the program was related to earlier sexual initiation. Among developing countries, six from 14 programs contributed to delaying the start of sexual intercourse, while among developed countries-16 from 38 programs [23, 24].

Adolescence is characterized by the intensity of the frequency of undertaking risky situations and the change of sexual partners is more frequent than among people over 25 years of age. The studies conducted by Woynarowska in 2005 indicated that $52,1 \%$ of young people who have already started sexual intercourse had only one partner, while every fourth person tested (13,1\% girls and 36,1\% boys) has had at least three partners [25].

Kirby's meta-analysis has shown that sexual education programs do not encourage the increase in frequency of sexual relations while some of them might even reduce it. Among 31 of studies, in nine (29\%) the decrease of frequency has been observed, $19(1 \%)$ have not resulted in significant changes and three of them (all in developed countries) have influenced the increase in frequency of sexual intercourse.

Regarding the number of sexual partners, the educational programs have not increased it and only some of them have caused its reduction. All over the world, 12 from 34 programs (35\%) have contributed to the decrease of the number of sexual partners, while $21(62 \%)$ programs have not have a significant impact on it. The percentage of programs that have had positive effect in developing and developed countries was practically the same. Only one program (in the US) might have contributed to the increase of the number of sexual partners. The programs were somewhat more effective among younger respondents [23, 24].

\section{Sexually transmitted diseases, with particular emphasis on HIV/AIDS}

The frequency of sexual intercourse and the number of sexual partners is reflected in the occurrence of the STD and the probability of pregnancy. There is a positive correlation between the age of sexual initiation and the incidence of STD. According to estimates, nearly 25\% of all STD infections are reported among adolescence. Only long-term, reliably planned and executed preventive measures can succeed in this field [12].

Youth is the group most exposed to the occurrence of new HIV infections. The European Council decided to incorporate HIV/AIDS awareness campaigns targeted to this age group (www.aids.gov.pl). Education and prevention are currently the only tools to fight HIV/AIDS [25].

According to SIECUS, neither restrictive education programs, nor complex sexual education indicated important relation between reduction of the risk of STD and lack of sexual education [22].

However, some studies show that health education including information about STD (also HIV/AIDS) might decrease the frequency of STD prevalence which might be also related to the lack of premature sexual initiation.

Haberland has reviewed evaluation studies of educational programs on sexuality and HIV, conducted in developed and developing countries in years 1990-2012. Out of 22 programs that met the inclusion criteria, 10 took into account the area of gender and power in a sexual relationship. Those programs were five times more effective and about $80 \%$ of them were associated with a significantly reduced rate of STD or unwanted pregnancy, while among programs that did not take into account gender and power relations, only $17 \%$ had such effect [26].

Ten studies evaluating the connection between carried out programs and changes in incidence rates for STD have been analyzed. Two of them have indicated positive influence, six of them have shown no significant impact, while another two have demonstrated adverse effects. To conclude, the studies indicate that health promotion programs can affect the frequency of the incidence of STD [24].

Uganda can serve as a good example of the fight against HIV/AIDS at the national level. Implemented ABC strategy has brought positive results - the percentage of people infected with HIV fell from almost $18.2 \%$ to $7 \%$ in the period 1992-2014 [27]. ABC strategy is based on:

A - abstinence - the promotion of sexual abstinence, reducing the number of sexual partners, delaying sexual initiation - especially among young women who make sexual relations with older men which significantly increases their risk of HIV infection, 
B - being faithful- recommending mutual fidelity in stable relationships

$\mathrm{C}$ - condom use - encouraging general and proper use of condoms [28].

$\mathrm{ABC}$ program causes much controversy and debate about its effectiveness, in recent years, a renewed increase in the percentage of people living with HIV (from 4.1\% in 2003 to $7 \%$ in 2014 ) has been observed [29].

\section{The use of condoms and other contraception methods}

UNAIDS (The Joint United Nations Programme on HIV and AIDS) recognized the male latex condom as the only and the most effective, currently available method for reducing the transmission of HIV and other sexually transmitted diseases [30,31]. Consistent and correct use of condoms during sexual intercourse protects against many STDs and unwanted pregnancy [32].

Laboratory in vitro studies indicate that latex condoms provide an effective physical barrier to pathogens STD [30].

The effectiveness of condoms is confirmed by the growing number of clinical trials. The strongest evidence comes from the cohort study, conducted on heterosexual couples in which one partner is infected with HIV. The study showed that consistent use of condoms reduces the risk of HIV infection by nearly $80 \%$ [33].

Woynarowska's study from 2005 showed that during the last sexual intercourse $11.1 \%$ of respondents did not applied any method of contraception, while methods of low efficiency (method of "natural" or rejected sexual intercourse) has been adopted by a total of $41.1 \%$ of respondents. Condom was the most widely used method of contraception [25].

HBSC (Health Behaviour in School-aged Children) study from 2010 confirms that the most common method of contraception among adolescents is a condom $(86.6 \%$ among middle school students and $89.0 \%$ among secondary school students). Subsequently, teenagers declared the use of rejected sexual intercourse (respectively $31.8 \%$ and $50.5 \%)$, a pill (17.1\% and $26.9 \%)$ and natural methods (16.1\% and $19.4 \%)$. Among the young people who underwent sexual initiation up to $15.1 \%$ of middle school students and $14.9 \%$ of secondary school students did not apply any method of contraception during their last intercourse. A condom was applied during last intercourse by $79.2 \%$ of middle school students and $69.9 \%$ of secondary school pupils [34].

Public Opinion Research Center in 2008 published a study which shows that the use of contraceptive methods is relatively common, but not sufficiently widespread and regular. The majority of respondents declares that they used contraception during their first sexual contact (61.1\%), most often a condom (85.2\%). 8,9\% of the respondents used a contraceptive pill [25].

The research of the Institute for Educational Research also shows that the most common method of contraception for young people is a condom. During the last sexual intercourse a condom was used by almost $65 \%$ of respondents, hormonal agents $-17 \%$, coitus interruptus - $12 \%$, counting the days since the last menstrual period - $8 \%$. As many as $11 \%$ of respondents did not use any method of contraception [20].

The percentage of sexually active Canadian teenagers who have declared using a condom during their last intercourse has been increasing in recent years. Among the participants of the B.C. Adolescent Health Survey questionnaire, the use of a condom increased from $64.6 \%$ in 1992 to $74.9 \%$ in 2003 . Among adolescents aged 1519 years participating in the Canadian Community Health Survey the use of a condom during the last intercourse increased from $72 \%$ in 2003 to $75 \%$ in 2005 . Although the proportion of condom use among the sexually active Canadian youth is clearly increasing, a downward trend in the use of condoms with age is also noticeable . Among 15-19 year-olds surveyed in the Canadian Community Health Survey, 81\% of sexually active $15-17$ year olds and only $70 \%$ of teens aged 18-19 reported using a condom during their last intercourse. Therefore, it can be concluded that many young people, not only in Canada, disregards the risk of STD infection [19].

Worldwide, 54 studies evaluated the impact of sexual education programs on the use of condoms. Almost half of the programs (48\%) resulted in an increase in the frequency of condom use, none of them had the effect of causing a reduction in the use of condoms. The percentage of successful programs in developing countries (seven of 12) was similar to the percentage in developed countries. The programs were equally effective regardless of the gender and age of the recipients.

Among 15 studies measuring the impact of sexual education programs on the frequency of the use of contraception in total, six have shown increased use of contraception, eight had no effect, and one (in the US) showed a reduction in the rate of contraceptive use [23, 24].

\section{Unwanted, teenage pregnancies and abortions}

The main public health problem in Poland and abroad are unwanted pregnancies, inextricably linked with many negative phenomena such as:

- teenage pregnancy (women who became pregnant and/or gave birth before turning 18), 
- increase of the likelihood of complications among adolescent pregnant mothers whose reproductive system is at an early stage of development,

- abortions (legal and illegal), abandonment of newborns and infanticide,

- increased risk of alcohol and smoking by the mother during pregnancy,

- increased risk of depression among women,

- reduction of the scope of prenatal care and the likelihood of breastfeeding by the mother after birth [35].

Sexual abstinence is the only way to completely protect teenagers against unplanned pregnancy and STD and which does not have any negative side effects. But it is not possible for all young people to choose to live in sexual abstinence and therefore programs on sex education should be carried out in order to prevent unwanted pregnancies and their negative effects such as abortion.

Studies show that pregnancy of women aged up to 15 years is associated with higher maternal mortality by nearly $60 \%$ compared to mature women. Child mortality also increased 2.5 -fold when the mother is under 20 [37]. Comparing with other age groups, there has been a 2 to 5 -fold more gynaecological problems, pregnancy pathology and abortion on demand among adolescents. In countries that have legalized abortion on demand, you can measure the extent of unwanted pregnancies on the basis of data on abortion on demand among minors. In France in 2003 the abortion rate for women aged $15-17$ was 9.6 per 1,000 [12].

Underage pregnancy may involve the risk of the following complications: premature placenta abruption, oligohydramnios, pregnancy-induced hypertension, renal neck-isthmic, premature birth and postpartum complications. The postpartum period is a significant emotional burden for a teenage mother and can lead to psychosocial problems. Minor pregnant women more likely than adults decide to put a child up for adoption [37].

According to the Central Statistical Office data, in Poland in 1998 the number of teen births (up to 19 years of age) was 20/1000 live births. In 2008 the number was 21 305, including 411 mothers who were under 15. In the period 2006 - 2008 unchanged increase in the number of births among young women up to 19 years of age was observed and the number of births by 15 year-olds and younger girls increased by $10 \%$. The younger the age group the greater was the increase in fertility - fertility of 15 -year-old increased by $63 \%$ between $2002-2010$, of 16 -year-old by $48 \%$, of 17 -year-old by $16 \%$, of 18 -year-old has not changed, and of the 19-year-old decreased by $12 \%$. Since 2010 a slight decrease in teen pregnancy has been observed [38]. Królikowska's study demonstrated that teenage pregnancy was the result of gaps in sexual education, and not for example of desire to escape from a dysfunctional home [39].

California Department of Public Health announced that the pregnancy rate of minors has dropped to 28 births per 1,000 teens aged 15-19. It is the lowest result since 1991 when it reached the highest value of 70.9/1000. The decrease in the number of births among teens occurred in all ethnic groups. California has several programs and strategies aimed at preventing teenage pregnancies. Some of the key elements include:

- state law which requires that school and other state-funded activities including sexual education were comprehensive, accurate from a medical point of view and adapted to the age and culture,

- local education programs for young people and their parents that provide information about sexual health, skills development, supportive environments and opportunities for young people,

- support for pregnant teenagers and teenage parents in order to strengthen the situation of young families.

Activities in California are holistic and fit in with the 3rd type of sexual education. The positive effects of the activities of the above-mentioned programs support the role of sexual education in promoting sexual health.

In Canada, where sexual education of the 3rd type is generally conducted, the pregnancy rate (including live births, abortions and miscarriages) for both younger (15 - 17 years) and older (18 - 19 years) teenage women significantly decreased over the past few decades. The pregnancy rate among 15-19 year-old women fell from 47.6 per 1,000 in 1995 to 29.2 per 1,000 in 2005. The most visible is the decrease in the number of pregnancies of 15-17 year old girls, for whom the rate fell from 28.51000 in 1995 to 15.8 per 1,000 in 2005 [19].

SIECUS reports that complex sexual education programs resulted in a 50\% decrease in the risk of teen pregnancy. By contrast, programs focused on abstinence had no effect on the number of teenage pregnancies [22].

Kirby's meta-analysis showed that in thirteen studies the impact of programs on the pregnancy rate was examined. Out of these 13 studies, in three of them positive effects were concluded, nine had a negligible impact, and one (in the US) suffered a significantly adverse effect [23, 24]. 
Table 1. Summary of numerical test results showing the impact of programs on sexual behavior

\begin{tabular}{|c|c|c|c|c|c|c|c|c|c|c|}
\hline \multirow[b]{2}{*}{ Results } & \multirow[b]{2}{*}{$\mathrm{N}^{*}$} & \multicolumn{3}{|c|}{$\begin{array}{c}\text { Studies in } \\
\text { developing } \\
\text { countries } \\
\mathrm{N}=18 \\
\end{array}$} & \multicolumn{3}{|c|}{$\begin{array}{c}\text { Studies in } \\
\text { developed } \\
\text { countries } \\
\mathrm{N}=65\end{array}$} & \multicolumn{3}{|c|}{$\begin{array}{l}\text { Total } \\
\mathrm{N}=83\end{array}$} \\
\hline & & - & 0 & + & - & 0 & + & - & 0 & + \\
\hline Delay of the moment of sexual initiation & 52 & 0 & 8 & 6 & 1 & 21 & 16 & 1 & 29 & 22 \\
\hline Reduction in the frequency of sexual relations & 31 & 0 & 3 & 2 & 3 & 16 & 7 & 3 & 19 & 9 \\
\hline Decrease in the amount of sexual partners & 34 & 0 & 5 & 3 & 1 & 16 & 9 & 1 & 21 & 12 \\
\hline Increase in the frequency of the use of a condom & 54 & 0 & 5 & 7 & 0 & 23 & 19 & 0 & 28 & 26 \\
\hline Increase in the frequency of the use of contraception & 15 & 0 & 2 & 0 & 1 & 6 & 6 & 1 & 8 & 6 \\
\hline Sexual risk reduction & 28 & 0 & 2 & 0 & 0 & 12 & 14 & 0 & 14 & 14 \\
\hline Reduction of the number of pregnancies & 13 & 0 & 1 & 1 & 1 & 8 & 2 & 1 & 9 & 3 \\
\hline Reduction of the number of STDs infections & 10 & 1 & 2 & 0 & 1 & 4 & 2 & 2 & 6 & 2 \\
\hline
\end{tabular}

*N - number of studies, which reported a profit; "+" - a positive (desirable) effect on factor; "0" - a statistically insignificant impact; "-" -a negative (undesirable) impact factor.

Source: [24].

The above summary of the studies clearly shows that the programs have a much more positive relation with the decrease in the frequency of engaging in risky sexual behaviours among the audience, than cause negative effects. Out of all 83 studies, nearly two-thirds (65\%) had significantly positive impact on at least one of the studied sexual behaviour or indicators, and only $7 \%$ significantly negative [24].

Studies comparing the results of the programs of type 1 and 2 conducted in the United States showed that education promoting only sexual abstinence does not produce favourable implications in terms of sexual behaviour of young people and the risks of teenage pregnancies compared to the model of comprehensive sexual education [1].

The phenomenon of unwanted pregnancies is permanently associated with the phenomenon of abortion. In 2012, as much as 1021 new-born babies were left after birth in hospital for reasons other than health, which may prove directly that the woman had an unwanted pregnancy. The number of abandoned new-borns increased by 263 compared to 2011. There are no data how many new-borns were abandoned by their mothers out of the hospital and the parents who are not Polish citizens. In 2012 a total of 752 abortions were carried out in accordance with the law, including 23 among women under 20 years of age [40].

\section{Conclusions}

Adolescence is characterized by frequent risk-taking behaviour. The task of health promotion is to influence health determinants, among others through sexual education. Studies confirm the positive impact of complex sexual education conducted according to the recommendations of international organizations on a lower frequency of engaging in risky sexual behaviour. It seems appropriate to take action in order to disseminate sexual education appropriate for the level of psychosexual development in schools.

\section{References:}

1. Biuro Regionalne WHO dla Europy i BzgA. Standardy edukacji seksualnej w Europie. Podstawowe zalecenia dla decydentów oraz specjalistów zajmujących się edukacją i zdrowiem. Lublin: Czelej; 2012 (in Polish).

2. World Association for Sexual Health. Declaration of Sexual Rights. 2014 [cited 2015 May 30]. Available from: www.worldsexology.org.

3. Adolescent health and development in the context of the Convention on the Rights of the Child, Committee on the Rights of the Child, [cited 2015 May 30]. Available from: www.unhchr.ch.

4. Ustawa z dnia 7 stycznia 1993r. o planowaniu rodziny, ochronie płodu ludzkiego i warunkach dopuszczalności przerywania ciąży (Dz.U. $1993 \mathrm{nr} 17$ poz. 78, z późn. zm.). 
5. Rozporządzenie Ministra Edukacji Narodowej z 12 sierpnia 1999r. w sprawie sposobu nauczania szkolnego oraz zakresu treści dotyczących wiedzy o życiu seksualnym człowieka, o zasadach świadomego i odpowiedzialnego rodzicielstwa, o wartości rodziny, życia w fazie prenatalnej oraz metodach i środkach świadomej prokreacji zawartych w podstawie programowej kształcenia ogólnego (Dz. U. Nr 67, poz. 756, z późn. zm.).

6. International Technical Guidance on Sexuality Education. An evidence-informed approach for schools, teachers and health educators. Volume II Topics and learning objectives. UNESCO 2009 [cited 2015 May 30 ]. Available from: www.unaids.org.

7. Wejbert-Wąsiewicz E, Stanisz J. Sto lat oświaty seksualnej w Polsce. Ideologia i polityka, a potrzeby społeczne, Kultura i Edukacja. 2009, 2(71): 27-52 (in Polish).

8. Ollis D, Harrison L, Richardson A, Building Capacity in Sexuality Education: The Northern Bay College Experience. Report of the first phase of the Sexuality Education and Community Support (SECS) project. School of Education Deakin University, Australia 2012.

9. Canadian Guidelines for Sexual Health Education, Public Health Agency of Canada 2003 [cited 2014 Aug 27]. Available from: www.phac-aspc.gc.ca

10. Izdebski Z, Niemiec T, Wąż K. (Zbyt) młodzi rodzice. Warszawa: Trio; 2011 (in Polish).

11. Międzynarodowa konferencja Młodzież, a AIDS. Materiały konferencyjne; 1999.

12. Flatow E. Zdrowie seksualne w postawach i zachowaniach studentów. Studium porównawcze na przykładzie Polski i Francji. Praca doktorska napisana pod kierunkiem prof. dr hab. M. Chomczyńskiej-Rubachy, 2011.

13. Mińko M, Barańska A, Religioni U, Religioni M, Mińko M, Burma S. Edukacja seksualna jako element kreowania polityki zdrowotnej w Europie. Hygeia Public Health 2014; 49(2): 348-352.

14. Ustawa z dnia 6 czerwca 1997r. Kodeks karny (Dz.U. 1997 nr 88 poz. 553 2014.01.27). Rozdział XXV.

15. Wąż K. Poglądy nastolatków na temat prokreacji. Rocznik Lubuski. 2006; 32(2): 137-148.

16. Beisert M. Seksualność w cyklu życia człowieka. Warszawa: Wydawnictwo Naukowe PWN; 2012 (in Polish).

17. Filipp E, Pawłowska A, Wilczyńska A, Kowalska B, Niemiec KT, Raczyński P, Kęsicka J. Metody planowania rodziny u nastolatek. Gin Prakt. 2005; 84(4): 46-52.

18. Zielińska M. Wychowanie seksualne wobec zmian zachowań seksualnych młodzieży polskiej - analiza wyników badań własnych. Gin Prakt. 2007; 15(2): 34-38.

19. McKay A, Bissell M. Sexual health education in the schools: Questions \& Answers (3rd Edition). Sex Information and Education Council of Canada (SIECCAN) 2010.

20. Instytut Badań Edukacyjnych. Opinie i oczekiwania młodych dorosłych (osiemnastolatków) oraz rodziców dzieci w wieku szkolnym wobec edukacji dotyczącej rozwoju psychoseksualnego i seksualności. Raport z badania. Warszawa 2015.

21. Grzelak S. Profilaktyka ryzykownych zachowań seksualnych młodzieży: aktualny stan badań na świecie i w Polsce. Kraków: Rubikon; 2009 (in Polish).

22. Kohler P. Abstinence-Only and Comprehensive Sex Education and the Initiation of Sexual Activity and Teen Pregnancy. Journal of Adolescent Health. 2008; 42(4): 344-351.

23. Kirby D, Barth RP, Leland N, Fetro JV. Reducing the risk: impact of a new curriculum on sexual risk-taking. Fam Plann Perspect. 1991; 23(6): 253-63.

24. Kirby D, Laris BA, Rolleri L. Impact of Sex and HIV Education Programs on Sexual Behaviors of Youth in Developing and Developed Countries. Youth Research Working Paper No. 2, Family Health International 2005.

25. Izdebski Z. Seksualność Polaków na początku XXI wieku. Studium badawcze. Kraków: Uniwersytet Jagielloński; 2012 (in Polish).

26. Haberland NA. The case for addressing gender and power in sexuality and HIV education: a comprehensive review of evaluation studies. International Perspectives on Sexual and Reproductive Health 2015; 41(1):31-42.

27. Uganda. UNAIDS [cited 2015 Aug 21]. Available from: www.unaids.org

28. Stammers T. As easy as ABC? Primary prevention of sexually transmitted infections. Postgrad Med J. 2005; 81(955): 273-275.

29. Ekwaru JP. The effect of Abstinence, Being faithful to one partner, and Condom use (ABC) messages on HIV infection among youth in Uganda. UC Berkeley Electronic Theses and Dissertations 2012 [cited 2015 Aug 21]. Available from: www.escholarship.org

30. Warner L, Gallo MF, Macaluso M. Condom use around the globe: how can we fulfil the prevention potential of male condoms? Sex Health. 2012; 9(1): 4-9. 
31. Condoms and HIV prevention: position statement by UNAIDS, UNFPA and WHO, [cited 2014 Aug 27). Available from: www.unaids.org

32. Centers for Disease Control and Prevention (CDC) Sexually transmitted diseases treatment guidelines. Morb Mortal Wkly Rep 2010, [cited 2015 Aug 27], 59(No. RR-12): 1-110. Available from: www.cdc.gov

33. Weller S, Davis-Beaty K. Condom effectiveness in reducing heterosexual HIV transmission (Review). The Cochrane Library. 2007 [cited 2015 Aug 16]; 4, CD003255. Available from: www.who.int

34. Mazur J, Małkowska-Szkutnik A. Wyniki badań HBSC 2010. Raport techniczny. Warszawa 2011.

35. Frankowicz-Gasiul B, Michalik A, Czerwińska A, Zydorek M, Olszewska J, Olszewski J. Ciąża młodocianych problem medyczny i społeczny. Studia Medyczne 2008; 11: 57-63.

36. Smothers MK, Smothers DB. A Sexual Assault Primary Prevention Model with Diverse Urban Youth. Journal of Child Sexual Abuse. 2011; 20(6): 708-727.

37. Padała O, Podgórniak M, Sadowska M,WdowiakA, Piróg M,Putowski M,ZawiślakJ. Młodociane macierzyństwo jako problem medyczny i społeczny. European Journal of Medical Technologies. 2014; 2(3): 61-65.

38. Szukalski P. Płodność i urodzenia nastolatek. Demografia i Gerontologia Społeczna - Biuletyn Informacyjny, 2011 [cited 2015 May 30], 4. Available from: www.dspace.uni.lodz.pl

39. Królikowska S. Sytuacja społeczna młodocianych matek. Dysfunkcje rodziny. Roczniki Socjologii Rodziny. 2011; 21: 79-101.

40. Sprawozdanie Rady Ministrów z wykonywania oraz o skutkach stosowania w roku 2012 ustawy z dnia 7 stycznia 1993 roku o planowaniu rodziny, ochronie płodu ludzkiego i warunkach dopuszczalności planowania ciąży (Dz.U. 1993 nr 17 poz. 78, z późn. zm.), [cited 2015 Aug 16]. Available from: www.orka. sejm.gov.pl 